\title{
ЗАРУБІЖНИЙ ДОСВІД ЗАПОБІГАННЯ КОРИСЛИВО-НАСИЛЬНИЦЬКИМ ЗЛОЧИНАМ, ЩО ВЧИНЯЮТЬСЯ ДІТЬМИ
}

\author{
СЕМЕНИШИН Микола Олександрович - кандидат юридичних наук, \\ докторант Донецького юридичного інституту МВС України
}

DOI:10.32782/NP.2020.1.21

УДК 343.915

У статті досліджено зарубіжний досвід запобігання корисливо-насильницьким злоиинам, що вчиняються дітьми. Аналіз зарубіжного досвіду свідчить про необхідність прийняття спеціалізованих законодавчих нормативно-правових актів з метою створення правового підгрунтя спещіально-кримінологічних заходів запобігання корисливо-насильницьким злочинам. З'ясовано, шо організаційну основу системи запобігання злочинам, учинених неповнолітніми, у багатьох зарубіжних країнах становлять як спеціалізовані профбілактичні установи, так $i$ органи та установи системи ювенальної юстииї. Аналіз досвіду запобігання корисливо-насильницьким злочинам у зарубіжних краӥнах (Англія, Канада, Нідерланди, Сполучені Штати Америки, Швейцарія) дозволив виділити напрями проведення ефективних заходів запобігання. На основі узагальнення зарубіжного досвіду, рекомендацій Европейсъкого Союзу, документів ООН та ЮНІСЕФ, автором запропоновано інновачійну модель трирівневої профілактики корисливо-насильницьких злочинів, щзо вчиняються дітьми, яка зумовлена передусім потребою в новій, більш ебективній системі реагування на такі кримінальні правопорушення та їх профілактики, з урахуванням мінімізачї покарання.

Ключові слова: зарубіжний досвід, дитина, неповнолітній, корисливо-насильницька злочинність, запобігання, профілакти$\kappa a$.

\section{Постановка проблеми}

Відповідно до Державної цільової соціальної програми «Молодь України» на 2016-2020 роки, схваленої розпорядженням Кабінету Міністрів України від 30 вересня 2015 р. № 1018-р, необхідність повноцінного розвитку та самореалізації молоді є однією із суспільних цінностей, а ії соціальна підтримка одним з основних пріоритетів державної політики. Потребують нагального розв'язання проблеми, що пов'язані 3 низьким рівнем зайнятості молоді на ринку праці за обраною професією та практичних вмінь і навичок молодих фахівців (у 2014 році в Україні рівень безробіття серед молоді віком 15-24 роки становив 23,1\%); слабкою мотивацією до дотримання молодими людьми здорового і безпечного способу життя; відсутністю сталої тенденції до зниження рівня злочинності у молодіжному середовищі, насильства та системної роботи у сфері їх профілактики [10].

ООН та ЮНЕСКО, Дитячий фонд ЮНІСЕФ та інші міжнародні організації значну увагу приділяють саме профілактиці негативних явищ у молодіжному середовищі. Багато зусиль докладається для пошуку нових чи адаптованих до сучасних умов життя підходів до здійснення профілактики правопорушень серед неповнолітніх. у цій справі, на наш погляд, цікавим є досвід інших країн, зокрема, США та Великобританії, які мають вагомі напрацювання у сфері організації профілактики правопорушень серед неповнолітніх. Англо-аме- 


\section{Кримінальне право, кримінальний процес та криміналістика}

риканська система профілактики правопорушень займає домінуюче і провідне становище в Європі, Америці та Японії [1, c. 43$]$.

Аналіз публікацій, у яких започатковано розв'язання даної проблеми

У правовій літературі різним аспектам, що стосуються проблем запобігання корисливо-насильницькій злочинності, приділяли увагу відомі вітчизняні та зарубіжні науковці: Ю. М. Антонян, Б. М. Головкін, В. В. Голіна, О. М. Джужа, А. І. Долгова, О. М. Костенко, О. М. Аитвинов, В. О. Меркулова, Н. С. Скриннікова, І. К. Туркевич, В. I. Шакун та ін.

\section{Виклад основного матеріалу}

Профілактика правопорушень у Великобританії та Америці здійснюється у трьох основних формах: ситуаційна, соціальна, превенція за допомогою громадськості.

Спеціалісти у сфері профілактики правопорушень залежно від того, у чому вони вбачають причини правопорушень, виокремлюють такі підходи до здійснення їх профілактики: структурний підхід, що пов'язує здійснення ефективної профілактики правопорушень 3 проведенням значних соціально-економічних перетворень у суспільстві; психологічний підхід, який визнає вирішальне превентивне значення впливу на особу потенційного правопорушника, а також осіб, які вже вчиняли правопорушення (з метою профілактики рецидиву); cumyаиійний підxiд, де вирішальна роль надається впливу на соціальні та фізичні фактори зовнішнього середовища, сукупність яких створюють сприятливу ситуацію для кримінальних проявів [2, с. 61-62].

У такий спосіб розрізняються концепції, орієнтовані на заходи загальної профілактики (структурний підхід), і теорії, що обгрунтовують необхідність спеціальних заходів профілактики (психологічний та ситуаційний підхід). При цьому особливу увагу британські й американські кримінологи приділяють заходам спеціальної профілактики.

Спеціальна профілактика здійснюеться на трьох рівнях:
- первинний рівень пробілактики, спрямований на усунення факторів зовнішнього середовища, які сприяють вчиненню правопорушень;

- вторинний рівень профбілактики, який має на меті попередити криміналізацію потенційних правопорушників і пов'язаний із впливом на нестійких осіб, у тому числі дітей «групи ризику»;

- третинний рівень пробілактики, спрямований на попередження рецидиву з боку осіб, що вже вчиняли правопорушення.

Первинна пробілактика правопорушень вважається у британській (як і в американській) кримінології вирішальною і базується на припущенні, що більшість правопорушень має ситуаційний характер і вчиняється в результаті певного збігу обставин, за наявності конкретних умов, що полегшують вчинення правопорушень. Сама ситуація стимулює та провокує на вчинення певних видів правопорушень. Ситуативна превенція, на відміну від вищезгаданих форм, спрямованих на блокування причин злочинності, впливає, насамперед, на скорочення можливостей для вчинення окремих злочинів. Суть цього методу полягає в організації підтримки держави пропагандистських кампаній із запобігання злочинам, розгляді проектів у сфері містобудування і забудов для створення середовища, вільного від злочинності, у зосередженні зусиль на виявленні та запобіганні можливостям для вчинення злочинів молоддю, а останнім часом - і в здійсненні тиску на ділові і промислові кола з метою внесення змін у практику, якщо вони можуть вплинути на зростання злочинності. На сьогодні у Великобританії, Франції, Нідерландах і деяких інших країнах ця форма запобігання є частиною офіційної політики боротьби зі злочинністю [3, c. 278].

Таким чином, найефективнішим напрямом превенції є своєчасне усунення криміногенних факторів зовнішнього середовища, а також створення антикриміногенних умов, за наявності яких правопорушник відмовиться від наміру вчинити правопорушення, а саме: умов, які зроблять вчинення правопорушень більш складною справою і відповідно зроблять об'єкт менш уразли- 
вим; які зроблять вчинення правопорушень ризикованішою та менш вигідною справою.

Останнім часом британські й американські науковці роблять акцент на здійсненні заходів соціальної профілактики правопорушень із залученням сил громадськості. Правопорушення виступають як соціальна проблема, у вирішенні якої участь має брати все суспільство.

Завдання, що постають перед соціальною профілактикою:

- поліпшення соціальних умов життя;

- посилення ролі соціальних інститутів;

- збільшення кількості можливостей для здобуття освіти, гідного працевлаштування, відпочинку [4, с. 687].

Цей вид профілактики правопорушень приділяє значну увагу роботі 3 дітьми, бо підліткове середовище вважається найпроблемнішим 3 погляду потенційної можливості вчинення правопорушень. Одним із напрямків здійснення соціальної профілактики є робота 3 дітьми у школах. У школах діти одержують основний обсяг інформації. Впровадження в програму шкільного навчання предметів, що сприяють вихованню дитини як законослухняного громадянина, лекцій та бесід з профілактики правопорушень, сприятиме правильному формуванню її особистості.

Слід зауважити, що британські й американські науковці дійшли висновку про необхідність об'єднання громадян за місцем проживання (під'їзду, будинку, двору, міста тощо) з метою підтримки чистоти, порядку на своїй території та гарантування безпеки своїх членів, що дозволить знизити рівень правопорушень. Такий вид профілактики отримав назву «профілактика за допомогою громадськості». Активну участь в організації профілактичної діяльності об’єднань громадян беруть працівники поліції. Вони надають громадянам консультативну та практичну допомогу. Найпоширенішими формами цього виду профілактики є реалізація програм «сусідська взаємодопомога», «зупини злочинця» тощо.

Вторинний рівень профілактики має на меті недопущення криміналізації тих осіб, чия поведінка та спосіб життя свідчать про можливість вчинення ними правопо- рушень. На відміну від заходів первинної профілактики, які мали загальний характер та спрямовувалися на усунення причин та умов вчинення правопорушень, заходи вторинної профілактики мають індивідуальний характер і пов'язані зі здійсненням впливу на особу, їі негативні риси, що визначають протиправну поведінку. Заходи вторинної профілактики базуються на прогнозуванні індивідуальної поведінки особи, яка складається із вивчення осіб, схильних до правопорушень, та джерел негативного впливу на них.

Специфічними заходами індивідуальної профілактики виступають різноманітні шкільні програми виховання та контролю за поведінкою неповнолітніх «групи ризику», а також програми, розраховані на профілактичну роботу з їх батьками. За кордоном такі програми реалізуються спільними зусиллями поліції, навчальних закладів, соціальних служб. Заходи індивідуальної профілактики повинні використовуватися дуже обережно, бо вони можуть викликати стигматизацію неповнолітніх та прискорити вчинення ними правопорушень.

Третинний рівень профілактики правопорушень має на меті профілактику рецидиву з боку осіб, які вже вчиняли правопорушення. Запобігання рецидиву пов'язується із застосуванням поліцейських, судових, пенітенціарних заходів, спрямованих на своєчасне виявлення осіб, що вчинили правопорушення, притягнення їх до відповідальності, а також застосування до них наявних засобів під час відбуття ними покарання.У профілактиці рецидиву особлива роль відводиться кримінально-правовим заходам впливу. 3 метою профілактики рецидиву широко використовуються також заходи підвищеного контролю за поведінкою осіб, які відбули покарання, а також програми їх індивідуальної реабілітації [5, с. 497-498].

Слід зауважити, що в ООН спеціальні структури запобігання злочинності існують уже понад 50 років. Так, відповідно до резолюції Генеральної Асамблеї ООН від 1 грудня 1950 р., кожні п'ять років проводяться міжнародні конгреси, що являють собою форуми з обміну політичними установками, стимулювання боротьби зі злочинністю та їі 


\section{Кримінальне право, кримінальний процес та криміналістика}

запобігання. Про важливість і популярність цих конгресів свідчить збільшення кількості країн-учасниць. Так, якщо на першому Конгресі ООН у 1955 р. у Женеві були присутні представники 40 країн, то на вісімнадцятому в 2014 р. у Відні - 145 держав [6, с. 144].

Прикладами закордонних програм, що орієнтовані на профілактику правопорушень серед дітей, є:

Truancy and Disaffected Pupils Programmer - програма, спрямована на зменшення кількості прогулів та кількості учнів, що негативно налаштовані проти школи. Ця програма реалізує заходи, спрямовані на вдосконалення процедури реєстрації учнів, які відсутні у школі; реагування на відсутність у школі у перший день; реалізацію освітніх програм для батьків; попередження шкільного хуліганства, погроз, знущань над однокласниками; роботу з прогульниками та нагляд за прогульниками; організацію тренінг-програм для вчителів та співробітників дитячих організацій 3 метою оволодіння ними спеціальними методами позитивного впливу на поведінку неповнолітніх та реагування на девіантну поведінку; покращення системи викладання у школі (Великобританія, США);

«Студенти для правосуддя» - ця програма здійснюється працівниками поліції спільно із вчителями навчальних закладів 3 метою ознайомлення учнів 3 різними сторонами правоохоронної системи. Під час реалізації програми 3 учнями проводяться рольові ігри. Учні поділяються на групи, які представляють поліцейських, прокурорів і суддів. Вони оглядають «місце правопорушення», допитують «свідків», «підозрюваних», звертаються по дозвіл на арешт, здійснюють судовий розгляд справ тощо. Адміністрація шкіл надає допомогу працівникам поліції в організації цих ігор. Реалізація цієї програми сприяє формуванню в учнів підвищеного відчуття поваги до правоохоронних органів, усувають відчуття недовіри до поліції, створює атмосферу довіри та взаєморозуміння (США) [7, с. 89].

Найефективніші програми базуються на мультифакторному підході та застосовуються, починаючи 3 періоду раннього дитинства, і спрямовані не стільки на індивіда (агресивна поведінка, стрес, навички подолання), скільки на несприятливі характеристики найближчого сімейного та соціального оточення. Вважаємо, що така програма може використовуватися для профілактики злочинності дітей, тому що досить часто причиною їх девіантної поведінки 6 недоліки в сімейному вихованні.

Деякі перспективні програми включають заміщення агресії, зокрема це Проєкт соціального розвитку м. Сієтла (Hill et al., 2001), Проєкт профілактики жорстокості серед молоді «Миротворці» (Embry et al., 1996), програма «Сім'я та школа разом» (FAST), які поєднують навчання батьків і візити додому зі шкільними заходами, спрямованими на покращення соціального функціонування підлітка в школі. Остання програма впроваджувалася в половині шкіл СIIA і продемонструвала високі показники утримання від агресії $\mathrm{i}$ по завершенню програми (Cornell, 2000) [7, с. 93].

3 метою профілактики пограбувань дітьми шкільного віку в основному, згадуються два проєкти - Позитивна зайнятість для молодих людей (широкий ряд розвиваючих активностей, особливо канікулярні програми) та Партнерство для безпеки шкіл (Safer School Partnership), включаючи чергування поліції в шкільному приміщенні, автобусі тощо, медіацію, позашкільні активності, бокс, туризм, індивідуальну роботу з групами ризику, інтерактивний вебсайт. Важливо, що утримуючі втручання не перешкоджають іншим ініціативам, і те, що до партнерства було залучено багато агенцій [7, с. 103].

У Великобританії для запобігання злочинам, що вчиняються дітьми створено особливі підрозділи «дитячої поліції», які працюють 3 молоддю до 17-річного віку, чия поведінка свідчить про їх деморалізацію. Між дирекцією шкіл і «дитячою поліцією» встановлено постійні контакти. При взаємодії з населенням британська поліція практикує три види контактів. Індивідуальний контакт, суть якого полягає в морально-психолоічній, контрольованій дії поліцейського на конкретну людину. У деяких містах створено спеціальні служби поліцей- 
ських чиновників зі зв'язку з населенням. Кожен, хто бажає, може прийти на прийом, отримати консультацію, пораду або надати інформацію, що цікавить поліцію. Найперспективнішими груповими контактами поліції і населення є тематичні зустрічі в університетах, коледжах, початкових школах. У деяких регіонах у навчальні програми шкіл запроваджується викладання предмета «Охорона громадського порядку». Столична поліція організовує підготовку юристів для виступу на радіо і телебаченні. Популярною протягом багатьох років залишається телерубрика «Поліцейська п'ятихвилинка» [8, с. 84-85].

У Канаді у програмах тривалого втручання зосереджують увагу на наданні допомоги дітям, які перебувають у соціально неприйнятних для їх особистісного розвитку умовах або мають схильність до асоціальної чи суспільно небезпечної активності. Програмні заходи, головним чином, формують позитивне ставлення до соціальних норм, правил, закону і суспільної моралі, освіти та корегують ставлення підлітка до правопорушень і злочинів, а також формують відповідальне ставлення до своїх вчинків, серед профілактичних заходів запобігання суспільно неприйнятній поведінці неповнолітніх можна виокремити правову, медикобіологічну та соціальну спрямованість.

Напрям соціальної превенції полягає в розширенні мережі обстеження дітей, залученні громадських організацій, батьків, вчителів та сусідів, що забезпечують ранню профілактику злочинної поведінки дітей. Крім того, канадські Girls Club of Canada/ America Programs i Services for At-Risk and Families створюються, реалізуються, фінансуються безпосередньо волонтерськими організаціями, школи залучають органи місцевого врядування й кошти місцевих, бюджетів. Програма Youth Inclusion Program заснована на добросусідських стосунках і застосовується у суспільно небезпечних районах [9, с. 58-59]. Вона спрямована на зниження рівня злочинності дітей та проявів антисуспільної поведінки шляхом створення безпечних місць, де молодь може отримати спеціальні навички та допомогу в навчанні. Позитивні приклади, які надають працівники та добровільні учасники програми, сприяють зміні ставлення молодих правопорушників до навчання й протиправної поведінки.

Соціальна спрямованість програм Boston Gun Project and Ope Ceasefire i Seattle Social Development Project відображає чітку взаємодію навчальних закладів й органів державної влади у справах дітей, правоохоронних органів та органів ювенальної юстиції, органів соціального забезпечення населення, а також безпосередньо батьків дітей, які беруть участь у реалізації програми. У канадській превентивній програмі спостерігається стала тенденція до залучення громадськості до здійснення заходів із запобігання злочинності неповнолітніх, які схильні до злочинної поведінки чи вчиняли правопорушення або злочини, що були віднесені до системи кримінального правосуддя [8, с. 95]

Більшість програм має комплексний характер, де зосереджено виховні, спостережні й корекційні заходи впливу на суспільно неприпустиму, у тому числі злочинну поведінку дитини.

Програми виховного, спостережного й корекційного характеру, як правило, мають тривалий характер (Fast Track, Olweus Bullying Prev Program, Life Skills Training, Leadership and Resiliency Program). Вони розраховані на дво- та трирічний вплив на процес розвитку дитини, які схильні до антисоціальної поведінки (наприклад, зловживання алкоголем, наркотиками, проявляють насильство до однолітків чи молодших учнів та агресію до тварин тощо), у період їх навчання у школі.

Кожний компонент програми виховного, спостережного спрямування передбачає окремий навчальний план, у якому передбачається: характеристика програми, детальний опис окремих груп заходів, зразки бланків (анкет), необхідні матеріали для реалізації цих компонентів та реплікаційні підказки, а також відповідне професійнокадрове забезпечення чи координаційний супровід.

Названі програми спрямовані на профілактику правопорушень серед неповнолітніх за рахунок залучення громадськості до 


\section{Кримінальне право, кримінальний процес та криміналістика}

цієї діяльності, пошуку для підлітків 3 «груп ризику» нових можливостей самореалізації. Ці програми мають суто профілактичний характер і приносять очікувані результати лише за умов активної участі всіх суб'єктів профілактики [7, с. 104].

Таким чином, варто констатувати, що зарубіжний досвід свідчить про дієвість прийняття спеціалізованих нормативноправових актів з метою створення правового підгрунтя спеціально-кримінологічних заходів запобігання корисливо-насильницьким злочинам, що вчиняються дітьми. Спостерігається тенденція до звуження функцій поліції з профілактики злочинності дітей та зосередження цих функцій у спеціалізованих соціальних та освітніх установах, а діяльність поліції й інших правоохоронних органів спрямовано переважно на припинення злочинів, а також їх рецидиву. Запобігання злочинності дітей грунтується, головним чином, на заходах допомоги, навчанні та вихованні, пріоритеті виховних заходів над виправними.

На основі узагальнення зарубіжного досвіду, рекомендацій Европейського Союзу, документів ООН та ЮНІСЕФ варто прийняти запропоновану у цій статті інноваційну модель трирівневої профілактики корисливо-насильницьких злочинів, що вчиняються дітьми, яка зумовлена передусім потребою в новій, більш ефективній системі реагування на такі кримінальні правопорушення та їх профілактики, з урахуванням мінімізації покарання.

\section{Висновки}

Вважаємо, що для подальшого становлення й розвитку вітчизняної системи профілактики правопорушень серед дітей, для розробки та впровадження у діяльність суб'єктів профілактики правопорушень нових, ефективних форм та методів запобігання необхідно вивчати і впроваджувати певні закордонні методичні напрацювання та практичні прийоми у цій сфері, але робити це необхідно з урахуванням національних особливостей, зумовлених попереднім розвитком нашої держави та сучасними транс- формаційними процесами, що відбуваються у всіх сферах суспільного життя.

На основі узагальнення зарубіжного досвіду варто виокремити головні напрями соціальної реабілітації дітей, які вчинили корисливо-насильницькі злочини в Україні: 1) створення і розвиток профілактичних служб для роботи 3 дітьми; 2) діагностика соціального середовища; 3) суспільна допомога і наставництво, з метою розв'язання найбільш важливих для дітей проблем; 4) робота посередницьких «патронажних» служб, що виражається у наданні підтримки дітям, особливо чутливим до конфліктів у сім'і, школі, на вулиці; 5) забезпечення належного місця проживання, здатного замінити сім'ю; 6) застосування сімейними соціальними працівниками спеціальних психологічних карт на кожну дитину конкретного мікрорайону 3 моменту народження 3 метою проведення своєчасних запобіжних заходів до досягнення нею повноліття;7) створення інституту сімейних соціальних працівників та закріплення кожної сім’і, яка має дитину, за місцем проживання, певним соціальним працівником, який взаємодіє 3 органами та установами охорони здоров'я; 8) правова пропаганда серед учнів освітніх установ працівниками ювенальної превенції, що є найважливішою складовою як освітніх програм, так і діяльності Національної поліції України з припинення девіантної поведінки дітей.

\section{入ітература}

1. Ведерникова О. Н. Современные тенденции развития ювенальной юстиции за рубежом. Российская юстищия. 2005. № 3.C. 43-47.

2. Коновалова И. А. Опыт борьбы с преступностью несовершеннолетних в Европе и СШІА. Адвокат. 2007. № 12. С. 59-69.

3. Ведерникова О. Н. Теория и практика борьбы с преступностью в Великобритании. Москва: PKA, 2014. 367 с.

4. Аунеев В. В. Курс мировой и российской криминологии : учебник. в 2 т. Москва: Юрайт, 2012. Т. 1 : Общая часть. $1003 \mathrm{c}$.

5. Профілактика злочинів : підручник / О. М. Джужа, В. В. Василевич, О. Ф. Гіда 


\section{АНОТАЦІЯ}

у статті досліджено зарубіжний досвід запобігання корисливо-насильницьким злочинам, щзо вчиняються дітьми. Аналіз зарубіжного досвіду свідчить про необхідність прийняття спеціалізованих законодавчих нормативно-правових актів з метою створення правового підгрунтя спеціально-кримінологічних заходів запобігання корисливо-насильницьким злочинам. 3'ясовано, що організачійну основу системи запобігання злочинам, учинених неповнолітніми, у багатьох зарубіжни краӥнах становлять як спеціалізовані профбілактичні установи, так $i$ органи та установи системи ювенальної юстииї. Аналіз досвіду запобігання корисливо-насильничьким злочинам у зарубіжних краӥнах (Англія, Канада, Нідерланди, Сполучені Штати Америки, Швейцарія) дозволив виділити напрями проведення ебективних заходів запобігання. На основі узагальнення зарубіжного досвіду, рекомендацій Европейсъкого Союзу, документів ООН та ЮНІСЕФ автором запропоновано інноваційну модель трирівневої пробілактики корисливо-насильницьких злочинів, що вчиняються дітьми, яка зумовлена передусім потребою в новій, більш ебективній системі реагування на такі кримінальні правопорушення та їх пробілактики, з урахуванням мінімізацій покарання.

Для подальшого становлення й розвитку вітчизняноӥ системи пробілактики правопорушень серед дітей, для розробки та впровадження у діяльність суб'єктів профілактики правопорушень нових, ебективних борм та методів запобігання необхідно вивчати $i$ впроваджувати певні закордонні методичні напрачювання та практичні прийоми у иій сбері, але робити це необхідно 3 урахуванням національних особливостей, зумовлених попереднім розвитком нашої держави та сучасними трансбормачійними процесами, що відбуваються у всіх сферах суспільного життя.

На основі узагальнення зарубіжного досвіду варто виокремити головні напрями сочіальної реабілітацій дітей, які вчинили корисливо-насильницькі злочини в Україні: 1) створення $i$ розвиток профілактичних служб для роботи з дітьми; 2) діагностика соиіального середовища; 3) суспільна допомога $і$ наставництво, з метою розв'язання найбільш важливих для дітей проблем; 4) робота посередницьких «патронажних» служб, шо виражається у наданні підтримки дітям, особливо чутливим до конбліктів у сім'і, школі, на вулииі; 5) забезпечення належного місия проживання, здатного замінити сім'ю; 6) застосування сімейними соціальними прачівниками спечіальних психологічних карт на кожну дитину конкретного мікрорайону з моменту народження з метою проведення своєчасних запобіжних заходів до досягнення нею повноліття; 7) створення інституту сімейних соціальних працівників та закріплення кожної сім'і, яка має дитину, за місцем проживання, певним сочіальним працівником, який взаємодіє з органами та установами охорони здоров'я; 8) правова пропаганда серед учнів освітніх установ працівниками ювенальної превенцій, щзо є найважливішою складовою як освітніх програм, так і діяльності Начіональної полічї Украӥни з припинення девіантної поведінки дітей.

Ключові слова: зарубіжний досвід, дитина, неповнолітній, корисливо-насильнищька злочинність, запобігання, пробілактика.

та ін.; за заг. ред. О. М. Джужи. Київ: Атіка, 2011. 720 c.

6. Криминальная политика и превенция: мировой опыт / общ. ред М. С. Крутера. Москва: Альта, 2015. 252 с.

7. Сучасні стратегії міліції щодо профілактики правопорушень серед неповноліт-

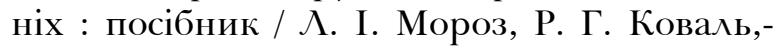
Д. М. Тичина та ін.; за наук. ред. А. І. Мороз. Київ: Вид. ПАЛИВОДА А. В., 2008.$210 \mathrm{c}$.

8. Преступность в современном мире / общ. ред В. М. Матвицкого. Москва : ИНTEP, 2016. $155 \mathrm{c}$.

9. Public Safety Canada Ottawa, Ontario. Canada K1 A 0P8. October 2014. P. 58-59.

10. Державна цільова соціальна програма «Молодь України» на 2016-2020 роки: розпорядження Кабінету Міністрів України від 30 верес. 2015 р. № 1018-р. Верховна Рада украӥни. URL: https://zakon.rada.gov.ua/laws/ show/148-2016-\%D0\%BF 


\section{Кримінальне право, кримінальний процес та криміналістика}

\section{FOREIGN EXPERIENGE IN THE PREVENTION OF CHILDISH AND VIOLENT CRIMES COMMITTED BY CHILDREN}

The article explores the foreign experience of preventing self-inflicted acts of violence committed by children. The analysis of foreign experience testifies to the necessity of adopting specialized legislative normative legal acts in order to create a legal basis for special criminological measures for the prevention of selfserving and violent crimes. It has been found that in many foreign countries, the organizational basis for preventing juvenile offenses is the specialized preventive and juvenile justice agencies. An analysis of the experience of preventing selfish and violent crimes in foreign countries (England, Canada, the Netherlands, the United States of America, Switzerland) made it possible to identify the directions of effective prevention measures. Based on the generalization of foreign experience, the recommendations of the European Union, UN documents and UNICEF, the author proposed an innovative model of three-level prevention of acts of violence and violence committed by children, which is primarily due to the need for a new, more effective system of responding to their legal response taking into account the minimization of punishment.

For further development and development of the domestic system of prevention of offenses among children, for the development and implementation of new, effective forms and methods of prevention of the subject of prevention of offenses it is necessary to study and implement certain foreign methodologi- cal developments and practical techniques in this field, but to do so taking into account the national peculiarities caused by the previous development of our country and the modern transformation processes occurring in all spheres of public life.

On the basis of generalization of foreign experience, it is necessary to identify the main directions of social rehabilitation of children who have committed acts of violence and violence in Ukraine: 1) creation and development of preventive services for work with children; 2) diagnosis of social environment; 3) community assistance and mentoring to address the most pressing issues for children; 4) the work of mediation "patronage" services, which is expressed in support of children, especially sensitive to conflicts in the family, at school, on the street; 5) providing a decent accommodation that can replace the family; 6) use by the family social workers of special psychological cards for each child of a particular neighborhood from the moment of birth with the purpose of holding timely preventive measures until she reaches majority; 7) Establishment of an institution for family social workers and the fixing of each family with a child at the place of residence by a certain social worker who interacts with health authorities and institutions; 8 ) legal advocacy among the pupils of educational institutions by the employees of juvenile prevention, which is the most important component of both educational programs and activities of the National Police of Ukraine for ending the deviant behavior of children.

Keywords: foreign experience, child, minor, self-serving, violent crime, prevention, prevention. 